\title{
Coexistence of cytotypes and chromosomal mosaicism in Hoplias malabaricus (Characiformes, Erythrinidae)
}

\author{
RENATA DA ROSA ${ }^{1,2}$, MARCELÉIA RUBERT ${ }^{3}$, LUIZ A C BERTOLLO $^{3}$, \\ ISABEL C MARTINS-SANTOS ${ }^{2}$ and LUCIA GIULIANO-CAETANO ${ }^{1}$
}

\author{
${ }^{1}$ Departamento de Biologia Geral, CCB, Universidade Estadual de Londrina. CEP 86051-990, Caixa Postal \\ 6001, Londrina, Paraná, Brasil. \\ 2 Departamento de Biologia Celular e Genética, Universidade Estadual de Maringá, CEP 87020-900, Caixa \\ Postal 331, Maringá, Paraná, Brasil. \\ ${ }^{3}$ Departamento de Genética e Evolução, Universidade Federal de São Carlos, CEP 13565-905, Caixa Postal \\ 676, São Carlos, São Paulo, Brasil.
}

\begin{abstract}
Karyotypes of seventeen Hoplias malabaricus specimens, collected in the fish culture station of UNOPAR (University of Northern Paraná), were analyzed. The station is in the Claro River system in the Tibagi River basin. Two distinct and coexistent karyotype forms (cytotypes) were identified, comprising either 42 chromosomes (cytotype A) or 40 chromosomes (cytotype C), both presenting metacentric and submetacentric chromosomes. In two specimens, one male and one female, it was not possible to characterize a modal diploid number because different cell lines were observed, with a predominance of $2 n=41$ and $2 n=42$ chromosomes at a frequency of $38.24 \%$ and $41.12 \%$, respectively. The karyotype with $2 \mathrm{n}=41$ showed some putative monosomic and trisomic chromosomes, while the karyotype with $2 \mathrm{n}=42$ showed 21 chromosomal pairs, similar to cytotype A. RAPD analysis showed that these two specimens have the same band profile of cytotype A (Nei's genetic identity=92\%), discarding a possible hybridization between both cytotypes and supporting the mosaicism hypothesis. These findings corroborate the isolation between cytotypes A and C.
\end{abstract}

Key terms: Hoplias malabaricus, chromosomal mosaicism, coexistence of cytotypes, RAPD, reproductive isolation.

\section{INTRODUCTION}

The family Erythrinidae comprises three genera: Erythrinus, with two reported species so far (E. erythtinus and $E$. kessleri); Hoplerythrinus, with three species $(H$. unitaeniatus, $H$. cinereus and $H$. gronovii); and Hoplias, composed of nine species and represented in Brazil by $H$. brasiliensis, H. lacerdae, $H$. macrophthalmus, $H$. microcephalus and $H$. malabaricus (Oyakawa, 2003). Although a small family, Erythrinids are taxonomically controversial, including several species lacking a precise identification.

Among these species, Hoplias malabaricus, commonly known as "traíra" or dogfish, is a carnivore and predator fish found throughout South America. They are considered an important food source in many regions (Oyakawa, 2003). This species inhabits lentic habitats, such as lakes, reservoirs and fish culture ponds, among others. They commonly occur in fish tanks through transportation of eggs and larvae by the water supply tanks. Supply water is often derived from impounded headwaters or from streams.

Several cytogenetic studies have been performed within this group, which actually represents a species complex (Bertollo et al., 2000). Among H. malabaricus populations, several karyotypic forms (cytotypes) were identified regarding

Corresponding author: Lucia Giuliano Caetano, Departamento de Biologia Geral - CCB - Universidade Estadual de Londrina, Londrina - Paraná - Brazil, C.P. 6001 - CEP: 86051-990, e-mail: giuliano@uel.br, Phone: 55 (43)33714417, Fax: 55 (43)33714527 
differences in diploid number and chromosomal morphology, as well as the absence/presence of diverse sex chromosome systems. Based on these features, seven distinct cytotypes (A-G) have been identified, and they have been used for comparative analyses among distinct populations (Bertollo et al., 2000). Some cytotypes, such as A and C, present a wide geographic distribution from Northern to Southern Brazil and also Argentina. In several regions different sympatric cytotypes are found, without any detectable hybrid forms among them (Bertollo et al., 2000).

Because of the remarkable chromosomal variability and the occurrence of different sympatric cytotypes, specimens of Hoplias malabaricus were studied in the present work, focusing on both cytogenetic and molecular features, to investigate the genetic events that occur in this population.

\section{MATERIAL AND METHODS}

Seventeen specimens of $H$. malabaricus from the fish farm station from UNOPAR (University of Northern Paraná) were collected and analyzed. The water supply for such fish culture is provided by the impounded headwaters of the Claro River, transformed into a lake. The water bodies drained from the tanks belong to the hydrographic system of the Claro River and Tibagi River basin (Tamarana City, Paraná State, Brazil). All analyzed specimens are native to this water system and are absolutely free from any kind of introduction or translocation.

Metaphase chromosomes were obtained through the air drying method (Bertollo et al., 1978) from kidney cells. The chromosomal classification was based on arm ratio, according to Levan et al. (1964).

In addition to the karyotype studies, a genomic DNA analysis using RAPD (Random Amplified Polymorphic DNA) was carried out. Total DNA was taken from muscle tissue samples of twelve specimens (seven from cytotype A, two mosaic specimens and three belonging to cytotype C). After digestion with proteinase $\mathrm{K}$ for twelve hours, phenol/Tris-HCl ( $\mathrm{pH}$ 8.0) was added, followed by centrifugation and a wash with phenol/Tris- $\mathrm{HCl}(\mathrm{pH} \mathrm{8.0)}$ and chloroform-isoamylic alcohol. After an additional centrifugation, chloroformisoamylic alcohol was added and the DNA was precipitated with absolute and cold ethanol for 12 hours at $-20^{\circ} \mathrm{C}$ and eluted in TE $1 / 10$ + RNAse.

DNA amplification was carried out according to Williams et al. (1990), with some modifications. Overall, sixty primers were examined, comprising 20 OPA, 20 OPB, and 20 OPW types. The primers OPA-07, OPA-09, OPA-11, OPA-12, OPA15 and OPB-08 generated a higher band polymorphism. The amplification products were analyzed through electrophoresis in agarose gel at $1.8 \%$ and stained with ethidium bromide.

The RAPD profiles were scored from the presence and absence of bands, corresponding to each amplified DNA fragment. TFPGA 1.3 software (Miller, 1997) was used to estimate genetic variability based on the rate of polymorphic locus, the heterozygosity and Nei's genetic distance (Nei, 1978).

A dendrogram based on genetic similarity values was obtained using the Jaccard (J) coefficient and UPGMA method using NTSYS-PC software (Rohlf, 1992). The reliability of branches was evaluated through bootstrap, using Bood software, with 1,000 replications (Coelho, 2000).

\section{RESULTS}

The chromosomal data obtained in the present work revealed the presence of two coexistent karyotypes in individuals from the UNOPAR fish culture station. Seven specimens (7 females) were classified as cytotype $\mathrm{C}$, according to Bertollo et al. (2000), with a diploid number of $2 n=40$ chromosomes $\mathrm{m} / \mathrm{sm}$ (meta/submetacentric) without sex differentiation, in a total of 175 metaphases analyzed (Fig. 1a), while, based on 200 metaphase counts, eight specimens ( 5 females and 3 males) were classified as cytotype $A$, with a diploid number of $2 n=42$ chromosomes $\mathrm{m} / \mathrm{sm}$ for males and females, 
without sex differentiation as well (Fig. 1b).

In two specimens, one male and one female, it was not possible to determine a single modal diploid number and two cell lines (with different diploid numbers) were found; one of them with a predominance of $2 n=41$ chromosomes and another with $2 n=42$ chromosomes, $38.24 \%$ and $41.12 \%$ in a total of 136 examined cells, respectively (Fig. 2), thus characterizing an intra-individual variation. The cell line with $2 \mathrm{n}=41$ was also monosomic for some chromosomal pairs, putatively identified as 7, 10 and 14, as well as trisomic in relation to other pairs, putatively identified as 4 and 21 (Fig. 3b).
The cell line with $2 \mathrm{n}=42$ chromosomes, showed a karyotype composed of $\mathrm{m} / \mathrm{sm}$ paired chromosomes, as expected for the pattern of cytotype A, described by Bertollo et al. (2000), (Fig. 3a).

RAPD analysis was carried in seven samples of cytotype $\mathrm{A}$, in both mosaic specimens and in three samples of cytotype C. The data showed that cytotypes $\mathrm{A}$ and $\mathrm{C}$ differed both in number and gel position of polymorphic bands for all primers. The two specimens lacking a specific diploid number presented, invariably, the same band profile of cytotype A individuals for all primers (Fig. 4).
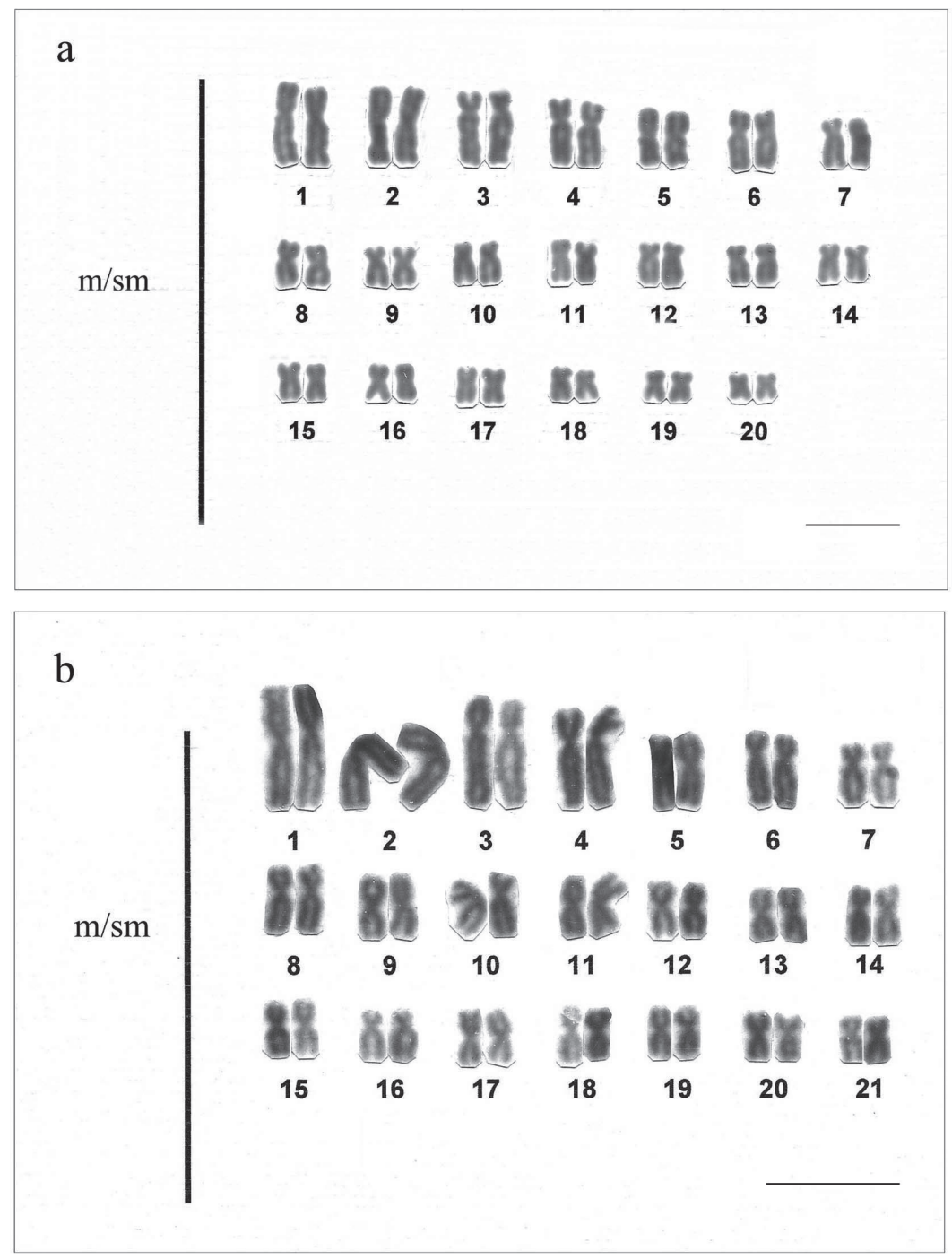

Figure 1: Karyotypes of $H$. malabaricus from UNOPAR: a) Cytotype C $(2 n=40)$; b) Cytotype A $(2 \mathrm{n}=42)$. Bar $=5 \mu \mathrm{m}$. 


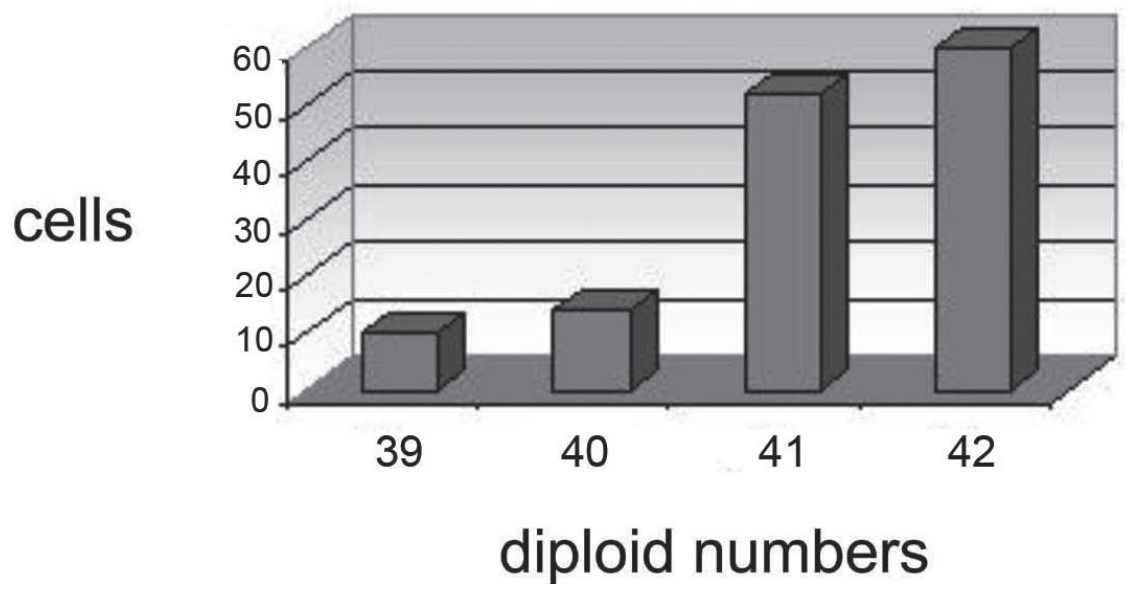

Figure 2: Frequency histograms of diploid numbers observed in mosaic specimens of $H$. malabaricus, showing a similar frequency of cells with $2 \mathrm{n}=41$ and $2 \mathrm{n}=42$ chromosomes.
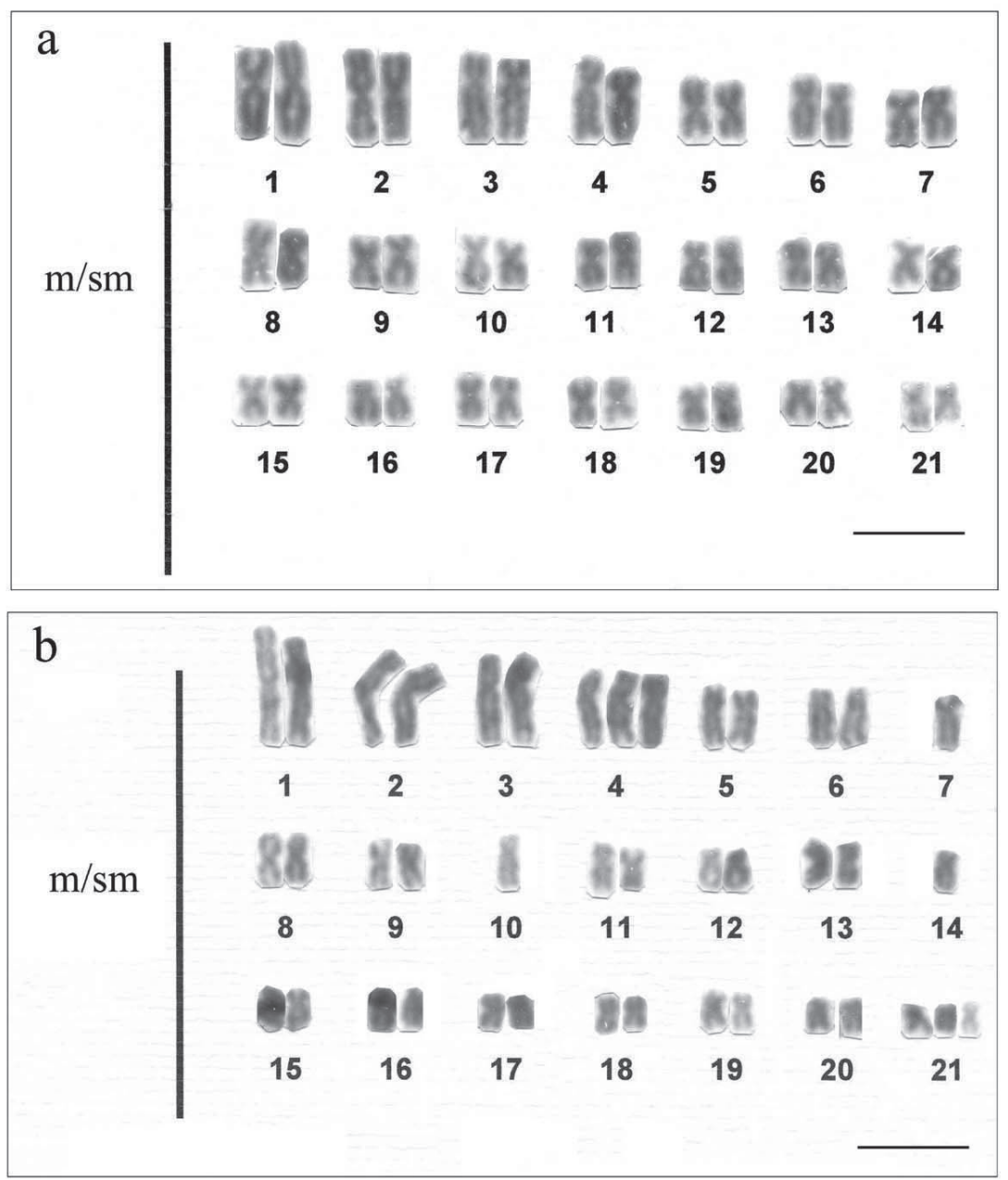

Figure 3: Karyotypes of the cell lines found within mosaic specimens of $H$. malabaricus: a) karyotype with $2 \mathrm{n}=42$ chromosomes; b) karyotype with $2 \mathrm{n}=41$ chromosomes, showing some monosomic and trisomic chromosomes. Bar=5 $\mu \mathrm{m}$. 


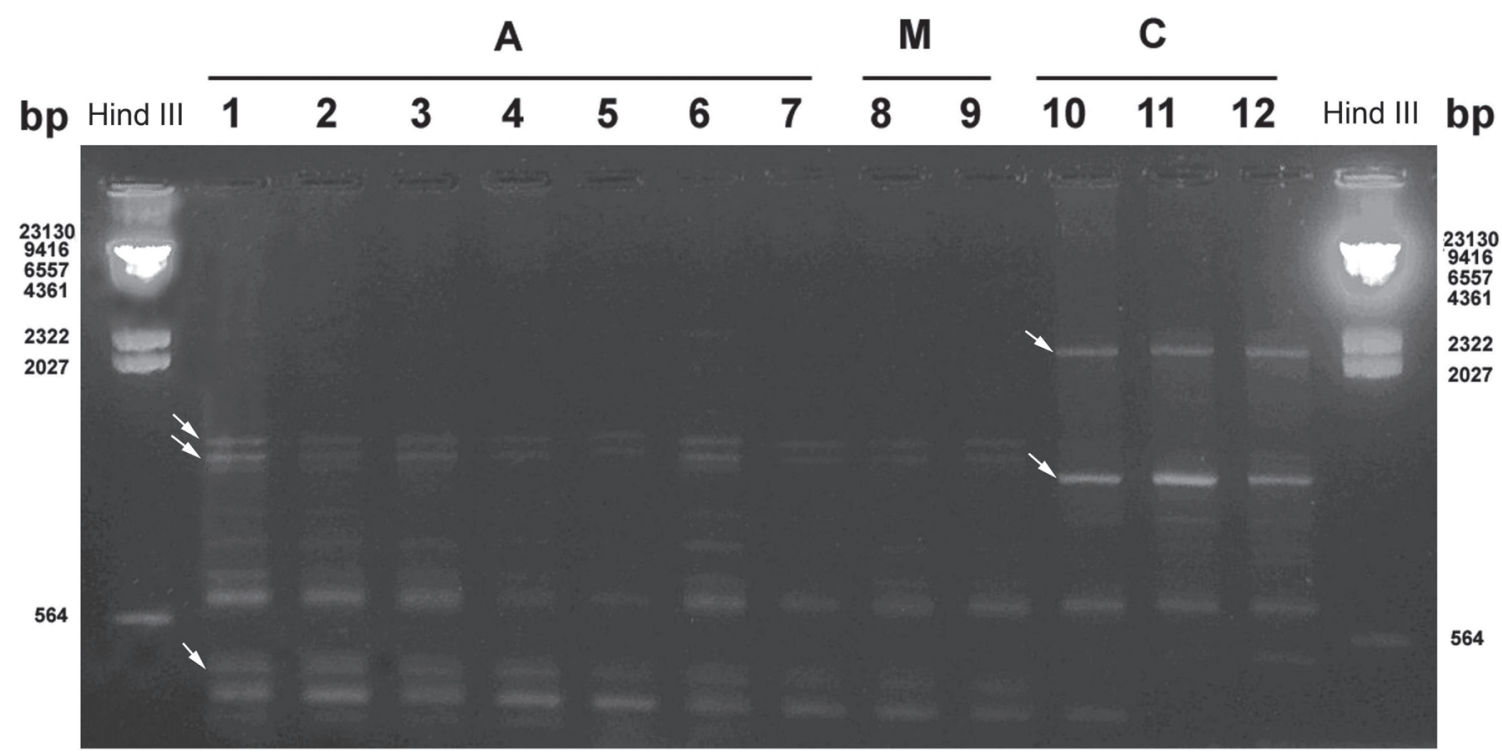

Figure 4: RAPD amplification products of H. malabaricus in agarose gel using the primer OPA-12. (bp) base pairs; (Hind III) Hind III Marker; (A) cytotype A samples; (M) mosaic specimens; (C) cytotype $\mathrm{C}$ specimens. The arrows indicate the invariable bands of each cytotype. Observe the similarity between band profiles in cytotype $\mathrm{A}$ and the mosaic specimens, as well as the presence of distinct bands in cytotype $\mathrm{C}$ specimens.

The set of six primers amplified 71 bands (loci), with a polymorphism rate of $23.94 \%$ for cytotype A specimens, $8.45 \%$ for the mosaic specimens, and $11.26 \%$ for cytotype $\mathrm{C}$ specimens. The heterozygosity was estimated at $0.118,0.046$ and 0.050 , respectively. Values of Nei's genetic distance were 0.083 between cytotypes A and the mosaic specimens, 1.321 between cytotype $\mathrm{A}$ and $\mathrm{C}$, and 1.022 between the mosaic specimens and cytotype $C$. The genetic similarity among individuals, estimated through Jaccard's coefficient, was equal to $92 \%$ between the mosaic and cytotype A samples, $26 \%$ between cytotypes $\mathrm{A}$ and $\mathrm{C}$, and $24 \%$ between mosaics and cytotype $\mathrm{C}$ individuals. The RAPD-based dendrogram showed a clustering between mosaic and cytotype A specimens, and a differentiation of $100 \%$ in relation to the cytotype $C$ sample, supported by bootstrap values (Fig. 5).

\section{DISCUSSION}

The three Erythrinidae genera (Hoplias, Hoplerythrinus and Erythrinus) show wide karyotypic diversity, comprising different cytotypes in Hoplias malabaricus (Bertollo et al., 2000), Hoplerythrinus unitaeniatus (Giuliano-Caetano et al., 2001; Diniz and Bertollo, 2003) and Erythrinus erythrinus (Bertollo et al., 2004). In the mentioned species, the cytotypes can be differentiated either by diploid number and/or chromosomal morphology, representing distinguishable and easily identified karyotypic forms. Furthermore, in $H$. malabaricus and E. erythrinus, the presence of distinct single or multiple sex chromosome systems leads to a precise identification of the several cytotypes observed.

Sympatry for the occurrence of distinct cytotypes has already been observed in some natural fish populations, such as Astyanax scabripinnis (Souza et al., 1995; Maistro et al., 2000; Fernandes and Martins-Santos, 2005), Laetacara cf dorsigera (Martins-Santos et al., 2005) and Hoplerythrinus unitaeniatus (GiulianoCaetano, 1988; Diniz and Bertollo, 2006). Different sympatric cytotypes have been reported in nearly nine distinct populations of the so-called $H$. malabaricus throughout 
Brazil and Argentina. Two such populations are characterized by the sympatry occurrence of cytotypes A $(2 n=42)$ and C $(2 n=40)$, one of them in the Igarapé Mindú - Manaus/AM system (Bertollo et al., 1997; Bertollo et al., 2000), and another in the Aguapey River - Corrientes/Argentina system (Lopes et al., 1998). Hybrid forms between cytotypes were not detected in any of the sympatric conditions, suggesting they are reproductively isolated. This can be considered a strong feature towards the characterization of distinct species.

In the present study, the coexistence of cytotypes $\mathrm{A}$ and $\mathrm{C}$ in the fish farm station was also ascertained. Most of the analyzed specimens presented karyotypes that allowed us to define them as representatives of each cytotype. Initially, the specimens in which the diploid number could not be defined, i.e., they presented a high number of both 41 and 42 chromosomes in metaphase spreads, might suggest they would be a result of hybridization events between the cytotypes A and C. However, an alternative hypothesis should be considered, related to non-disjunction events in cytotype A individuals, giving rise to cell lines bearing trisomies and monosomies and hence leading to cells with 41 chromosomes.

Torres et al. (2002) detected a drastic reorganization in the karyotype of Trichomycterus paolence, with diploid numbers ranging from 54 to 57 chromosomes in kidney cells. They observed the presence of normal-sized chromosomes and microchromosomes, probably resultant from chromosomal breakages and consequent formation of acentric fragments that would be lost during the cell cycle. In another species of the same genus, $T$. davis, three cell lines with different diploid numbers $(2 n=54$ to 56$)$ were also identified, probably derived from both mitotic non-disjunction $(2 \mathrm{n}=55)$ and chromosome fission $(2 \mathrm{n}=56)$ (Borin and Martins-Santos, 2000).

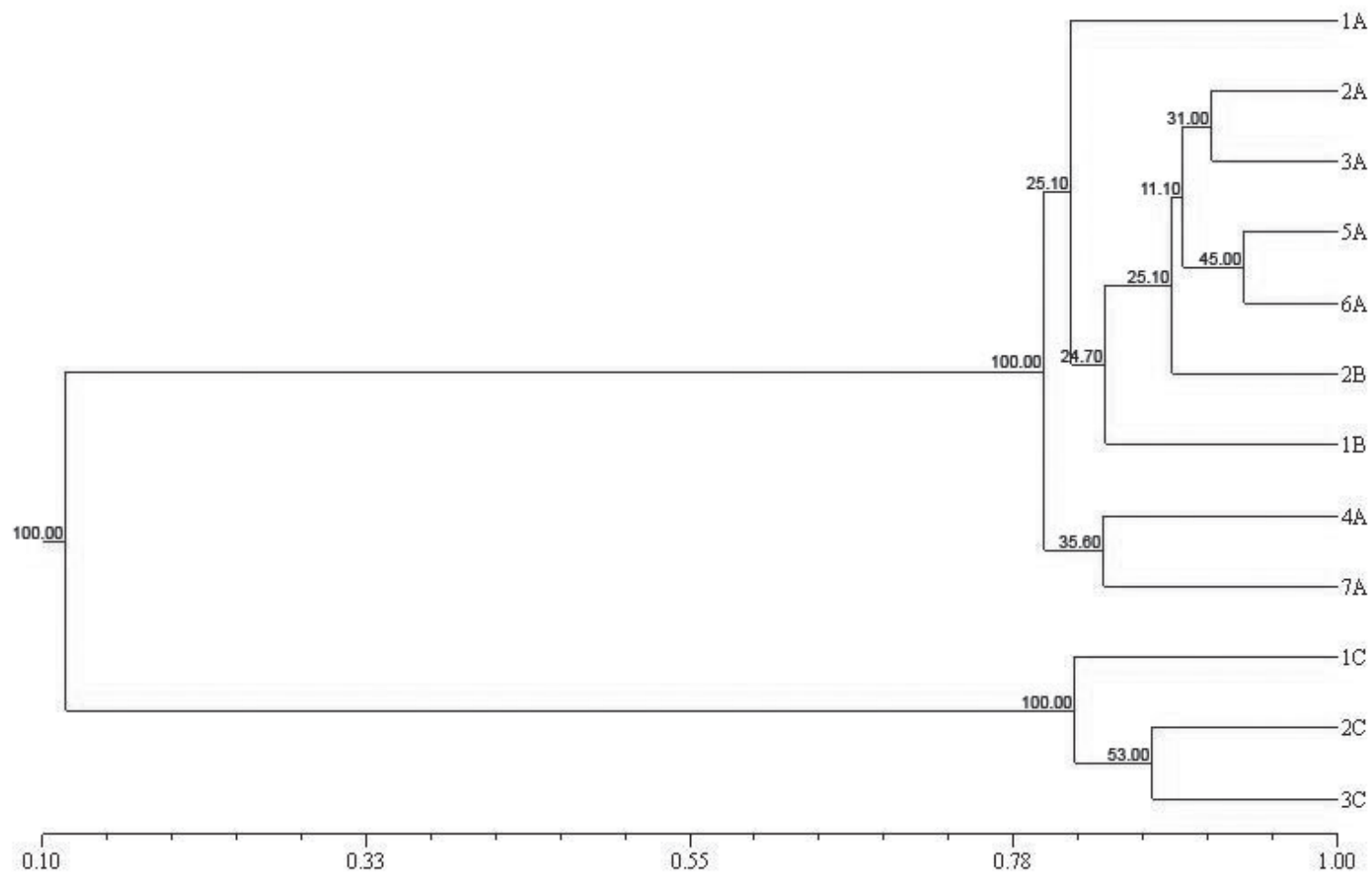

Figure 5: Genetic similarity dendrogram, based on RAPD profiles, in H. malabaricus. Observe the clustering between mosaic specimens (B) and those belonging to cytotype A, as well as the distance in relation to cytotype $\mathrm{C}$ specimens. 
The distinct band profiles obtained by RAPD analyses provided a reliable identification of cytotypes $\mathrm{A}$ and $\mathrm{C}$, revealing a genomic differentiation between both cytotypes and their putative reproductive isolation. These data corroborate the hypothesis that the species H. malabaricus must represent a species complex with different cytotypes (Bertollo et al., 2000). Nonetheless, the two mosaic specimens showed a similar RAPD pattern obtained within cytotype A sample, which weakens the hypothesis that they originated through hybridization between the two cytotypes. Therefore, the different cell lines appear to be a consequence of chromosomal alterations (non-disjunction) in the early mitotic divisions of zygotes belonging to the cytotype A. Moreover, the similarity dendrogram based on RAPD profiles also reinforces the close relationship between cytotype A and mosaic specimens, as well as their higher distance in relation to cytotype C. Nevertheless, the precise causes for the mosaicism observed in this study cannot be addressed, suggesting that further studies are still required.

\section{ACKNOWLEDGMENTS}

We would like to thank the Coordenação de Aperfeiçoamento de Pessoal de Nível Superior (CAPES), Universidade Estadual de Maringá and Universidade Estadual de Londrina for their support.

\section{REFERENCES}

BERTOLLO LAC, TAKAHASHI CS and MOREIRAFILHO O (1978) Cytotaxonomic considerations on Hoplias lacerdae (Pisces, Erythrinidae). Brazilian Journal of Genetics 1: 103-120

BERTOLLO LAC, MOREIRA-FILHO O and FONTES MS (1997) Karyotipic diversity and distribuition in Hoplias malabaricus (Pisces, Erythrinidae): Cytotypes with $2 \mathrm{n}$ $=40$ chromosomes. Brazilian Journal of Genetics 20: 237-242

BERTOLLO LAC, BORN GG, DERGAM JA, FENOCCHIO AS and MOREIRA-FILHO O (2000) A biodiversity approach in the neotropical Erythrinidae fish, Hoplias malabaricus. Karyotypic survei, geographic distribution of cytotypes and cytotaxonomic considerations. Chromosome Research 8: 603-613

BERTOLLO LAC, OLIVEIRA C, MOLINA WF, MARGARIDO VP, FONTES MS, PASTORI MC,
FALCÃO JN and FENOCCHIO AS (2004) Chromosome evolution in the erythrinidae fish, Erythrinus erythrinus (Teleostei: Characiformes). Heredity 93: 228-233

BORIN LA and MARTINS-SANTOS IC (2000) Intraindividual numerical chromosomal polymorphism in Trichomycterus davisi (Siluriformes, Trichomycteridae) from the Iguaçu River basin in Brazil. Genetics and Molecular Biology 23: 605-607

COELHO ASG (2000) Software BOOD: Versão 2,0 Avaliação de dendrogramas baseados em estimativas de distâncias/similaridades genéticas através do procedimento de bootstrap. UFG, Goiânia

DINIZ D and BERTOLLO LAC (2003) Karyotypic studies on Hoplerythrinus unitaeniatus (Pisces, Erythrinidae) populations. A biodiversity analysis. Caryologia 56: 303-313

DINIZ D and BERTOLLO LAC (2006) Intra- and interindividual chromosome variation in Hoplerythrinus unitaeniatus (Pisces, Erythrinidae). A population from the Brazilian São Francisco river basin. Genetics and Molecular Biology 29: 453-458

FENOCCHIO AS and BERTOLLO LAC (1988) A simple method for fresh-water fish lymphocyte culture. Brazilian Journal of Genetics 11: 847-852

FERNANDES CA and MARTINS-SANTOS IC (2005) Sympatric occurrence of three cytotypes and four morphological types of B chromosomes of Astyanax scabripinnis (Pisces, Characiformes) in the River Ivaí Basin, state of Paraná, Brazil. Genetica 124: 301-306

GIULIANO-CAETANO L and BERTOLLO LAC (1988) Karyotype variability in Hoplerythrinus unitaeniatus (Characiformes, Erythrinidae). I. Chromosome polymorphism in the rio Negro population (Manaus, state of Amazonas). Brazilian Journal of Genetics 11: 299-306

GIULIANO-CAETANO L, JORGE LC, MOREIRA-FILHO $O$ and BERTOLLO LAC (2001) Comparative cytogenetics studies in Hoplerythrinus unitaeniatus populations. Cytologia 66: 39-43

LEVAN A, FREDGA K and SANDBERG AA (1964) Nomenclature for centromeric position on chromosomes. Hereditas 52: 201-220

LOPES PA, ALBERDI AJ, DERGAM JÁ and FENOCCHIO AS (1998) Cytotaxonomy of Hoplias malabaricus (Osteichthyes, Erythrinidae) in the Aguapey River (Province of Corrientes, Argentina). Copeia 2: 485-487

MAISTRO EL, OLIVEIRA C and FORESTI F (2000) Sympatric occurrence of two cytotypes of Astyanax scabripinnis (Characiformes, Characidae). Genetics and Molecular Biology 23: 365-369

MARTINS-SANTOS IC, PORTELA-CASTRO ALB and JULIO Jr. HF (2005) Chromosomal polymorphism and speciation in Laetacara cf. dorsigera (Teleostei, Perciformes, Cichlidae) from the river Paraná PR Brazil. Caryologia 58: 95-101

MILLER MP (1997) Tools for population genetic analyses (TFPGA) 1.3: A Windows program for the analysis of allozyme and molecular population genetic data. Computer software distributed by author

NEI M (1978) Estimation of average heterozigosity and genetic distance from a small number of individual. Genetics 89: 583-590

OYAKAWA OT (2003) Family Erythrinidae (Trahiras). In REIS RE, KULLANDER SO and FERRARIS Jr. CJ (eds) Check List of the Freshwater Fishes of South and Central America. Porto Alegre: Edipucrs. pp: 238-240

ROHLF FJ (2002) NTSYS-pc. Numerical taxonomy system, v. 2.1. Exeter publishing Ltd., Setauket NY 
SOUZA IL, MOREIRA-FILHO O and BERTOLLO LAC (1995) Cytogenetic diversity in the Astyanax scabripinnis (Pisces, Characidae) complex. II. Different cytotypes living in sympatry. Cytologia 60 : 273-281

TORRES RA, FORESTI F and OLIVEIRA C (2002) Occurence of karyotypical mosaicism in
Trichomycterus paolence (Teleostei, Trichomycteridae). Caryologia 55: 283-287

WILLIAMS JGK, KUBELIK AR, LIVAK L, RAFALSKI

JA and TINGEY SV (1990): DNA polymorphisms amplified by arbitrary primers are useful as genetic markers. Nucleic Acids Research 18: 6531-6535. 